\title{
Low Dose Spinal dan Epidural untuk Seksio Sesarea Pasien dengan Patent Ductus Arteriosus
}

\author{
Devi Ariani ${ }^{1}$, Isngadi ${ }^{2}$ \\ ${ }^{1}$ RSUD Kab. Kepulauan Meranti, Riau, ${ }^{2}$ Departemen/SMF Anestesiologi dan Terapi Intensif, Fakultas Kedokteran \\ Universitas Brawijaya- RSUD. Dr. Saiful Anwar Malang, Jawa timur
}

\begin{abstract}
Abstrak
Wanita hamil dengan penyakit jantung bawaan terjadi perubahan hemodinamik peningkatan kardiovaskular, perhatian dan terapi yang khusus dibutuhkan. Penambahan obat opioid meningkatkan dosis anestesi lokal, hemodinamik stabil, meningkatkan efek analgetik. Kasus: Satu, wanita 26 tahun gravida 30-32 minggu, PDA besar L-R shunt, hipertropi konsentrik ventrikel kiri, trivial atrium regurgitasi, pulmonal regurgitasi sedang, trikuspid regurgitasi sedang, pulmonal hipertensi berat, EF 57\%. Dua, wanita 22 tahun gravida 37-38 minggu, preterm premature rupture of membrane, PDA besar L-R shunt, pulmonal hipertensi berat, penurunan fungsi sistolik ventrikel kiri, EF 54\%, bekas seksio sesarea. Keduanya menggunakan teknik regional anestesi dosis rendah. Pembahasan: Teknik menggunakan combine spinal epidural (CSE) dengan spinal 5 mg bupivacain heavy 0,5\% dan fentanyl $50 \mathrm{mcg}$, epidural bupivacain 0,125\% dan fentanyl $30 \mathrm{mcg}$ meningkatkan anestesi untuk seksio sesarea, dan hemodinamik stabil pada pasien kelainan katup. Opioid intratekal mereduksi anestesi lokal dan hipotensi, kemampuan anestesi terjaga. Simpulan: Dosis rendah CSE dengan $5 \mathrm{mg}$ bupivacain heavy $0,5 \%$ dan $50 \mathrm{mcg}$, dengan epidural bupivacain $0,125 \%$ dan fentanyl $30 \mathrm{mcg}$ adekuat untuk pasien seksio sesarea dengan kelainan jantung.
\end{abstract}

Kata kunci: ibu hamil; penyakit jantung bawaan; seksio sesarea

\section{Low-dose Spinal and Epidural Patients for Caesarean Section Patients with Patent Ductus Arteriosus}

\begin{abstract}
Pregnant women with congenital heart diseases hemodynamic changes during pregnancy increasing cardiovascular, it's need attention and special treatment. Opiod addition scan decrease the dose of local anesthetic drugs, prevent hemodynamic fluctuation, increase the analgesia effect. Case: First case, female 26 years with gravida 30-32 weeks with large PDA Left to Right shunt, consentrik left ventrikel hipertrophy, trivial atrium regurgitation, moderate pulmonal regurgitation, moderate tricuspid regurgitation, severe pulmonal hypertension, EF 57\%. Second case, female 22 years with gravida 37-38 weeks, PPROM, large PDA Left to Right shunt, pulmonal hypertension severe, function systolic left ventrikel decreasing, EF 54\%, former section caesaria. Both of them undergoing section caesaria with low dose regional anesthesia. Discussion: In this case with used CSE with Spinal $5 \mathrm{mg}$ Bupivacaine heavy 0,5\% and fentanyl $50 \mathrm{mcg}$, Epidural bupivacain 0,125\% and fentanyl $30 \mathrm{mcg}$ provided adequate anaesthesia for section cesarean delivery, and haemodynamic stability in patient with valvular cardiac disease. The synergism between intrathecal opioid sareductionin the dose of local anaesthetic and reduce hypotension, while still maintaining adequate anaesthesia. Conclussion: Low dose CSE with $5 \mathrm{mg}$ bupivacaine heavy $0,5 \%$ and fentanyl $50 \mathrm{mcg}$, and epidural bupivacain $0,125 \%$ and fentanyl $30 \mathrm{mcg}$ provided adequate for sectio cesarian patient with cardiac disease, with stable of haemodynamic.
\end{abstract}

Key words: caesarian section; congenital heart diseases; pregnancy 


\section{Pendahuluan}

Ibu hamil dengan penyakit jantung bawaan (PJB) perlu perhatian dan penanganan khusus dan multidisiplin, karena terjadinya perubahan fisiologis selama hamil akan menambah beban kerja jantung, sedangkan jantungnya sendiri sudah ada kelainan dengan kemampuan kompensasi dan daptasi terhadap kehamilan yang tidak sempurna. Pada wanita hamil dengan PJB perubahan hemodinamik selama kehamilan melampaui kemampuan jantung untuk berkompensasi, sehingga resiko kejadian kardiovaskuler semakin meningkat. Selain itu pada saat persalinan secara spontan maupun pembedahan juga terjadi perubahan hemodinamik dan terjadi nyeri yang semua itu memperberat beban kerja jantung hingga berakibat fatal. ${ }^{1,2}$

Kelainan bawaan pada jantung dan sistem kardiovaskular terjadi pada 7 sampai 10 per1.000 kelahiran hidup (0,7\%-1,0\%).Penyakit jantung bawaan merupakan bentuk yang paling sering dari penyakit bawaan dan berjumlah kira-kira 30\% dari seluruh insiden penyakit bawaan. Menurunnya insiden penyakit jantung rematik, menjadikan penyakit jantung bawaan merupakan penyebab utama penyakit jantung. Kira-kira 10\%-15\% dari anak penderita penyakit jantung bawaan tersebut juga menderita penyakit bawaan pada skeletal, genitouranius, atau sistem gastrointestinal. Tabel dibawah ini menunjukkan 9 lesi jantung bawaan yang merupakan 80\% dari penyakit jantung bawaan. ${ }^{3}$ Prevalensi penyakit jantung kongenital (PJB) di Eropa, telah diketahui sebesar 8,2 per 1000 kelahiran hidup, dengan tipe kelainan terbanyak berupa ventricular septal defect (VSD) 2.6 per 1000 kelahiran hidup, atrial septal defect (ASD)1.6 per 1000 kelahiran hidup, persistent ductus arteriosus (PDA) 0.9 per 1000 kelahiran hidup, pulmonary stenosis (PS) 0.5 per 1000 kelahiran hidup, tetralogy of Fallot (TOF) 0.3 per 1000 kelahiran hidup, coarctation of the aorta 0.3 per 1000 kelahiran hidup, transposition of the great arteries (TGA) 0.3 per 1000 kelahiran hidup dan stenosis aorta 0.2 per 1000 kelahiran hidup. ${ }^{4}$ Penyakit jantung bawaan yang paling umum pada wanita hamil $60 \%$ terdiri atas persistent ductus arteriosus (PDA), atrial septal defect (ASD) dan ventricular septal defect (VSD), ${ }^{2,4} \mathrm{Di}$ Amerika Serikat, komplikasi penyakit jantung ditemukan sekitar 4\% dari seluruh kehamilan. Maternal dengan penyakit jantung memiliki resiko mortalitas sebesar (10\%-25\%). Penyakit jantung kongenital pada maternal ditemukan 3 kali lebih sering dibanding dengan penyakit jantung yang didapat. $15 \%$ pasien obstetri yang masuk ICU kausanya karena penyakit jantung. Lima puluh persen kematian maternal di ICU disebabkan oleh kehamilan dengan penyakit jantung. ${ }^{2}$ Penyakit jantung bawaan sebenarnya harus dikoreksi tetapi di negara berkembang mengalami keterbatasan jumlah dokter ahli, fasilitas pemeriksaan penunjang dan tingginya angka kemiskinan, menyebabkan banyak orang dengan kelainan jantung bawaan yang tidak menjalani pembedahan perbaikan pada penyakit jantung bawaannya.

Hal ini merupakan kendala apabila anak atau orang dewasa dengan kelainan jantung bawaan menjalani pembedahan non kardiak. Karena resiko untuk pembedahan non kardiak akan meningkat berupa gagal jantung, hipertensi pulmonal dan sianosis. Pada saat ini, sekitar $90 \%$ dari bayi yang lahir dengan penyakit jantung bawaan (PJB) dapat hidup mencapai dewasa, dan sebagai akibatnya, ada peningkatan jumlah wanita mencapai usia subur. Namun, kehamilan pada wanita dengan PJB menambah beban hemodinamik pada jantung yang dapat mengakibatkan komplikasi lebih berat dibandingkan dengan kehamilan pada populasi umum. ${ }^{2}$

Walaupun sebagian pasien dengan PJB dapat mentoleransi kehamilan dengan baik, namun ada sebagian yang tidak mampu mentoleransi perubahan fisiologis yang terjadi pada masa kehamilan, ini menyebabkan peningkatan resiko komplikasi pada ibu maupun janin yang dikandung. Ibu hamil dengan PJB berhubungan dengan kejadian kardiovaskuler pada maternal berupa gagal jantung, aritmia, stroke, dan kematian. Maternal PJB juga berpengaruh terhadap janin dalam kandungan berupa pertumbuhan janin yang terganggu, berat badan lahir rendah, meningkatnya resiko kelahiran 
preterm, meningkatnya resiko janin meninggal dalam kandungan dan meningkatkan resiko mortalitas perinatal. ${ }^{2}$

\section{Kasus}

\section{Kasus 1}

Wanita usia 26 tahun dengan diagnosis G1P0A0 gr 30-32 minggu, PDA besar L-R shunt, hipertropi konsentrik ventrikel kiri, trivial Atrium Regurgitasi, Pulmonal Regurgitasi sedang, Trikuspid Regurgitasi sedang, Pulmonal hipertensi berat, EF 57\%, yang dilakukan SCTP dengan mengunakan anestesi regional dosis rendah.

\section{Anamnesa}

A: -; M: sildenafil 3x $50 \mathrm{mg}$, furosemid 20-20-0; P: asma -, HT-, DM -, jantung bawaan + ( pda + , hipertensi pulnonal); L: puasa 6 jam preoprasi; E: penyakit jantung bawaan sudah dirasakan dari kecil, bila berlari sesak dan kebiruan dibibir. Saat ini pasien bila pasien naik tangga terasa sesak dan bila berbaring terlentang terasa sesak.

\section{Pemeriksaan Fisik}

B1: airway bebas paten, buka mulut $>3$ jari, TMD $>5 \mathrm{~cm}$, mallampati 1, nafas spontan, gerakan dada simetris, RR 32x/min, $\mathrm{SpO}_{2} 99 \%$ nrbm lpm, suara nafas simetris, vesikuler. rhonki, wheezing (-/-); B2: akral hangat, kering, merah; CRT $<2$ detik, tekanan darah 128/60 $\mathrm{mmHg}$, nadi 102

Tabel 1. Insidensi Kelainan Jantung Bawaan

\begin{tabular}{ll}
\hline Lesi & $\begin{array}{l}\text { Insidensi } \\
(\%)\end{array}$ \\
\hline Asianotik & 35 \\
Ventikular septal defect & 9 \\
Atrial septal defect & 8 \\
Patent ductus arteriosus & 8 \\
Pulmonal stenosis & 6 \\
Aortic stenosis & 6 \\
Coartctation of the aorta & 3 \\
Arterioventicular septal defect & \\
Sianotik & 5 \\
Tetralogy of Fallot & 4 \\
Transposition of the great arteries & \\
\hline
\end{tabular}

kali/ menit, kuat angkat regular. Jantung suara S1 dan S2 tunggal reguler murmur $(+)$ sistolik 4/6 di mid clavicula kiri ics 3-4, gallop (-); B3: compos mentis, GCS 456; B4: terpasang urine kateter 50 cc/inisial; B5: sesuai usia kehamilan; B6: pitting edema di ekstremitas bawah.

\section{Pemeriksaan Penunjang}

Darah lengkap: hb $11.60 \mathrm{mg} / \mathrm{dL}$; leukosit $12.470 \mathrm{~mm}$; hematokrit 34.90; trombosit $300.000 \mathrm{~mm}$; natrium $136 \mathrm{mg} / \mathrm{dL}$; kalium $3.97 \mathrm{mg} /$ $\mathrm{dL}$; cloride $105 \mathrm{mg} / \mathrm{dL}$; OT/PT 28/9, albumin 3.03, Gds 76, ureum 15.90, kreatinin 0.47. Analisa gas darah $\mathrm{pH} 7.48, \mathrm{PaCO}_{2} 27,0, \mathrm{PO}_{2}$ 200.5, $\mathrm{HCO}_{3}$ 20.2, BE -3,5 saturasi 99,5; USG Kebidanan: Tampak janin intrauterine $\mathrm{T} / \mathrm{H}$, letak bujur kepala di bawah. Placenta implantasi di fundus s/d corpus posterior; maturasi gradeI.

\section{Ecocardiografi}

PDA besar Right to left shunt; PH severe; Hipertrofi konsentrik LV; Trivial Atrium Regurgitasi; Moderate Mitral Regurgitasi; Moderate Pulmonal Regurgitasi; moderate Trikuspid Regurgitasi; severe Pulmonal Hipertensi.

Teknik anestesi dilakukan regional anestesi dengan combine spinal epidural (CSE). Regimen spinal: bupivacain heavy $0,5 \% 5 \mathrm{mg}+$ fentanyl 50 mcg. Regimen Epidural: Bupivacain 0,125\% + fentanyl $30 \mathrm{mcg}$ dengan $15 \mathrm{cc}$. Direncanakan dipasang invasif monitor CVC dan arteri line. Post operasi perawatan ICU. Pasiendirawat2 hari di ICU dengan homodinamik relatif stabil. Pemberian regimen epidural analgesia Bupivacain 0,125\%+mo $1 \mathrm{mg}$ total volume 8-12 cc diberikan. Medikamentosa setelah operasi menggunakan cefazoline $2 \times 1$ gram, ranitidin 2 x $50 \mathrm{mg}$ (iv), kalnex 3 × $500 \mathrm{mg}$, vit c 1 x 1 ampul, furosemid 20-20-0 mg (iv), antrain $3 \times 1$ gr, Sildenafil 2 x $50 \mathrm{mg}$ peroral.

\section{Kasus 2}

Wanita usia 22 th dengan diagnosis G2P1A0 37-38 minggu, PPROM, PDA besar L-R shunt, Pulmonal Hipertensi berat, penurunan fungsi sistolik ventrikel kiri bekas SCTP yang dilakukan SCTP dengan regional anestesi dosis rendah. 


\section{Anamnesa}

A: - M: (-); P: asma (-), HT (+) tidak minum obat, DM (-), jantung (+) PDA diketahui saat hamil L: puasa 6 jam preoperasi; E: pasien mengeluh keluar cairan dari jalan lahir sejak 5 jam sebelum masuk rumah sakit, sesak nafas bila jalan jauh atau naik tangga, aktivitas sehari-hari tidak merasa sesak.

\section{Pemeriksaan Fisik}

B1: airway bebas paten, buka mulut $>3$ jari, TMD $>5 \mathrm{~cm}$, malampati 1 , nafas spontan, gerakan dada simetris, RR 32 x/menit, $\mathrm{SpO}_{2} 99 \%$ nasal kanul 2-4 lpm, suara nafas simetris vesikuler. Rhonki-/-, wheezing-|-; B2: akral hangat, kering, merah, CRT $<2$ detik, tekanan darah 140/80 mmhg, Nadi 86 x/ menit, kuat angkat reguller, suara jantung S1 dan S2 tunggal reguler murmur 4/6 di left parasternal line $S$ gallop (-/-); B3: compos mentis, GCS 456; B4: buang air kecil spontan B5: sesuai usia kehamilan; B6: edema ekstremitas bawah.

\section{Pemeriksaan Penunjang}

Darah lengkap: hb $10.3 \mathrm{mg} / \mathrm{dL}$; leukosit 7.100 $\mathrm{mm}$; hematokrit $31,7 \%$; trombosit $249.000 \mathrm{~mm}$; natrium $134 \mathrm{mg} / \mathrm{dL}$; kalium 4,09 mg/dL ; cloride 110 mg/dL; OT/PT 16 / 6, albumin 3,24, Gds 71, ureum 14,2 , kreatinin 0.58 . Analisa gas darah $\mathrm{pH}$ 7.48, $\mathrm{PaCO}_{2} 27,0, \mathrm{PO}_{2} 200.5, \mathrm{HCO}_{3} 20.2$, BE -3,5 saturasi 99,5 .

\section{Ecocardiografi}

PDA besar L to R shunt diameter $1 \mathrm{~cm}, \mathrm{PH}$ severe (PASP 64). Fungsi sistolik LV menurun EF 54\%. LV dilatasi.

Teknik anestesi dilakukan regional anestesi dengan combine spinal epidural (CSE). Regimen spinal: Bupivacain heavy 0,5\% $5 \mathrm{mg}+$ fentanyl $50 \mathrm{mcg}$. Regimen Epidural: Bupivacain 0,125\% + fentanyl $30 \mathrm{mcg}$ dengan total volume $15 \mathrm{cc}$. Direncanakan dipasang invasif monitor CVC dan arteri line. Post operasi perawatan ICU. Pasien dirawat 3 hari di ICU dengan homodinamik relative stabil. Pemberian regimen epidural analgesia Bupivacain 0,125\% + mo $1 \mathrm{mg}$ total volume $8-12$ cc diberikan. Medikamentosa setelah operasi menggunakan cefadroxyl 3x500 mg tab, kalnex 3x 500mg tab, roboransia $1 \mathrm{x}$, methergin 3x1. Didapatkan hasil hemodinamik yang stabil. Regimen yang digunakan yaitu regimen spinal: Bupivacain heavy $0,5 \% 5 \mathrm{mg}+$ fentanyl $50 \mathrm{mcg}$, dan regimen epidural: bupivacain $0,125 \%+$ fentanyl 30 mcg dengan total volume $15 \mathrm{cc}$.

\section{Pembahasan}

Pada wanita yang sedang hamil terjadi perubahan-perubahan anatomi dan fisiologi yang bermakna. Banyak diantaranya melibatkan sistem kardiovaskuler secara langsung maupun tidak langsung, secara umum pada ibu hamil akan terjadi peningkatan kebutuhan pada sirkulasi jantung, arteri, dan vena. Dimana curah jantung basal akan meningkat sekitar $30-40 \%$ dengan peningkatan maksimum tercapai pada akhir trisemester ke-2 kehamilan. Selain itu pada ibu hamil dengan penyakit jantung bawaan juga memerlukan perhatian khusus. Perubahanperubahan ini akan mempengaruhi tehnik anestesi yang akan digunakan sehingga akan terdapat perbedaan jika dibandingkan dengan tehnik anestesi pada pasien yang tidak hamil. ${ }^{2,5,6,10}$

\section{Pra Anestesia}

Ketepatan diagnostik pra anestesi sangat menentukan pilihan anestesi dan outcome pada pasien ibu hamil dengan kelainan jantung. Pada penilaian preoperatif problem dasar dan peningkatan resiko dari pasien harus dapat diidentifikasi. Evaluasi klinis sebaiknya dilengkapi dengan data laboratorium, ECG, foto thorax, echocardiography, dan informasi lainnya untuk menunjang diagnosa dan prognosanya. Pada pasien ini memiliki cardiac risk asscessment menurut WHO dikategorikan kelas fungsional IV, karena memiliki penyakit jantung bawaan dengan diperberat adanya hipertensi pulmonal, dan idealnya pada kelas fungsional IV tidak direkomendasikan untuk hamil mengingat resiko morbiditas dan mortalitasnya tinggi. Wanita hamil dengan penyakit jantung yang signifikan atau kompleks harus dikelola oleh sebuah tim center spesialis center (multidisipliner). Tim ini harus mencakup perwakilan dari kebidanan, anestesiologi, neonatologi, kardiologi, intensif care, keperawatan, dan pekerjaan sosial. 
Pasien harus dilihat secara berkala selama kehamilan mereka dan rencana pengelolaan harus dirumuskan pada awal kehamilan sebelum timbulnya gejala. Wanita berisiko tinggi harus dikelola oleh ahli anestesi yang berpengalaman dalam mengobati pasien hamil dengan kelainan jantung seperti pada kasusini., ${ }^{2,10}$

\section{Anestesi dan Intraoperatif}

Berbagai teknik anestesi untuk seksio sesarea banyak dibahas, baik berupa teknik regional maupun anestesi umum. Di antaranya ada berbagai pro dan kontra, resiko akan jatuhnya resistensi vaskuler sistemik (SVR) belum dapat disingkirkan dengan penggunaan anestesi regional. Permasalahan yang timbul pada penggunaan anestesi umum dan ventilasitekanan positif adalah penurunan venous return dan cardiac output dikarenakan tekanan intratorakal. Penurunan ini akan berakibat pada peningkatan pirau dari kanan ke kiri. Pada kasus ini dipilih dengan menggunakan anestesi regional yaitu combine spinal epidural. Pada laporan kasus ini, menggunakan dosis rendah bupivakain hiperbarik $(5 \mathrm{mg})$ dikombinasikan dengan fentanyl $50 \mathrm{mcg}$ untuk menghasilkan blok yang adekuat dengan efek samping sistemik yang minimal antara lain untuk meminimalisir penurunan tahanan sistemik vaskular dan mencegah timbulnya hipotensi pada anestesi spinal.

Dikarenakan aliran darah uterus tidak bersifat autoregulasi, maka perfusi uteroplasental berhubungan secara langsung dengan tekanan darah ibu. Karena itu penurunan tekanan darah ibu masih dapat ditoleransi oleh ibu tetapi tidak oleh janin. Salah satu strategi untuk mempertahankan hemodinamik yang stabil selama dilakukan spinal anestesi pada seksio sesarea dengan menggunakan bupivacain dosis rendah yang dikombinasikan. Pada laporan kasus ini tidak menemukan adanya episode hipotensi dan desaturasi. ${ }^{2,10}$

Teknik yang menyediakan analgesia yang efektif dengan dosis minimal, onset lambat terhadap perubahan hemodinamik adalah yang ideal. Anestesi lokal neuraksial akan menyebabkan penurunan simpatik di SVR dan hipovolemia relatif. Hal ini perlu diantisipasi adanya penurunan
SVR dengan penggantian volume yang tepat dan bijaksana dalam penggunaan vasokonstriktor. Alasan lain dipilihnya regional pada kasus ini adalah faktor koagulasi dan pembekuan darah pada pasien ini masih dalam batas normal. ${ }^{2,10}$

\section{Simpulan}

Kehamilan dapat memberikan resiko yang tinggi pada pasien dengan penyakit jantung kongenital yang diperberat dengan hipertensi pulmoner. Meskipun demikian proses kehamilan dan kelahiran dapat berjalan dengan sukses apabila setiap kasus ini dapat ditegakkan diagnosa dan mendapatkan penanganan secara multidisipliner. Managemen ibu hamil dengan kelainan jantung kongenital ini harus dilakukan mulai dari masa awal kehamilan dan sampai dengan paska persalinan. Apabila pasien membutuhkan operasi, maka pilihan anestesi baik regional maupun umum disesuaikan dengan kondisi pasien. Paskaoperasi pasien dengan kondisi seperti kasus ini harus tetap dipantau dengan ketat untuk menghindari kemungkinan terjadinya perburukan pirau atau fenomena tromboemboli yang mungkin terjadi pada paska operasi.

Pada kasus ini menggunakan teknikspinal: bupivacaine heavy $0,5 \%+$ fentanyl $50 \mathrm{mcg}$, dan epidural: bupivacain $0,125 \%+$ fentanyl $30 \mathrm{mcg}$ sebanyak 15 cc terbukti hemodinamik stabil pada pasien kelainan jantung.2 Pasien dengan low dose spinal menurunkan mortalitas pasien. Dapat dijadikan alternatif penatalaksanaan anestesia pada pasien PJB. ${ }^{2}$

\section{Daftar Pustaka}

1. Hirabayashi Y, Shimizu R, Fukuda H, Saitoh $\mathrm{K}$, Igarashi T. Soft tissue anatomy within the vertebral canal in pregnant women. British Journal of Anaesthesia; 1996;77(2):153-6.

2. Isngadi. Manajemen Anestesi Pada Kehamilan Dengan Penyakit Jantung, UB Press,Malang; 2017; 34, 60-78.

3. Hines Roberta and Marschal Katherine Obstetric Anesthesia: Principles and 
Practice. 5th Edition. New York: Churc; 2010.19(4):471.

4. Chang AB. Physiologic changes of pregnancy. Obstetric AnesthesiaPrincipleand Practice; 2004. 2: 15-27.

5. Chestnut David H .Chesthnut'sObstetricAn esthesia: Principlesand Practice 5th Edition. Elsevier; 2010.

6. Kinsella SM, Whitwam JG, Spencer JAD. Aortic compressionby the uterus: Identification with the Finapres digital Arterial pressure instrument. $\mathrm{Br} \mathrm{J}$ Obst Gynecol; 1990. 97:700-5.
7. Kuo C-D, Chen G-Y, Yang M-J, Tsai Y-S. The effect of position in autonomic nervous activityin late pregnancy. Anaesthesia; 1997.52:1161-5.

8. Sadaniantz A, Laurent LS, Parisi AF. Longterm effects of multiple pregnancies on cardiac dimensions and systolic and dyastolic function. Am J Obstet Gynecol; 1996; 174:1061-4.

9. DattaS, KodaliB,SegalS.ObstetricAnesthesia Handbook. 2010.

10. Bisri T, Wahjoeningsih, Suwondo BS. Anestesiobstetrik: Anatomi dan Fisiologi Wanita Hamil. KATI; 2013. 1-14. 